\title{
The role of Political Parties in New Social Movements with special reference to Women's in India
}

\author{
*Dr. Namrata Kothari \\ * Assistant Professor and HOD, BHKMahavidyalaya,Department of Political Science
}

\begin{abstract}
This paper seeks to address the discussion on governance, democracy and civil society by explaining two sets of relationships which till now is less discussed things among the scholars: between women and political parties, and between political parties and social movements that organise women in India. It shows some of the limitations and possibilities of the relationships, arguing that it is necessary one, both to the social movements seeking to pursue their agendas through the political system, and to political parties needed to be open to broad public participation and to maintain strong links on the ground issue.
\end{abstract}

Keywords: electoral participation,social movements, political parties, nationalism.

In India, there has been little analysis of the relationship between progressive movements and political parties. This needs to be addressed, to the better understand the dynamics and possibilities of the relationships. History clearly demonstrates the leading role that movements play in shifting the public agenda and opening up the space for far reaching social and environmental reforms.These advances, can be more far-reaching when progressive MPs and political parties work in union to develop campaigns and effect change.Women's political engagement at the state level has devoted a great deal of attentions in which states have undermined gender inequality. Women's interest are not adequately addressed by most of the political parties because of male patriarchial structure in Indian society. But women have played important and prominent roles in state, national and grass-roots levels in social movements but much less attention to political parties are given. There are the stances of representation and participation of women's are ignored.Those women who have played leading roles in political parties have solemnly addressed women's interests and questions of gender inequality.

Keeping in view, the above backdrop, the present paper seeks to find out the answer of the following research questions.

- How political parties matter for the struggle for women's right in the decision- making process in India.

- Are parties an effective vechile for minorities? How is support for women's rights disturbed along left and right spectrum?

- What are the reasons behind this support? Are they play significant role in recognition of rights in political field and promoting policies and legislative change in their favour?

- How successful have women's movement been when they have tried to strengthen parties commitment to gender equality? A second kind of social movements with which parties have allied is the ethnic / religious movements. What implications has this had for women's participation?

- How far women's participation increases because of reservation and quotas?

- To what extent have women's movement exploited parties need for women's votes by pressuring them to address certain issues or to honour their pre-election commitments?

The deep-rooted prejudices concerning women and gender resulted in under - representation of women in party politics. It is a common belief in South Asia that men are better equipped than women to exercise power in public sphere. Women who have been involved in politics often characterize the political world as dirty and corrupt and fear that their involvement may endanger their reputations. Parties have done less to provide women access to network and resources that help them to climb up in the ranks of party hierarchies. Another important obstacle to women's electoral participation in the growing violence at elections in South Asia. Many parties combine conservative views on gender with support for certain forms of women's rights and empowerment. Sometimes, the pressures from domestically and internationally led recalcitrant parties to concede to certain feminist demands.There is a rich literature on women's activism in social movements, in contrast to the literature on political parties. Democracy movements in Pakistan, peace movements in Srilanka and struggles of poor rural women in Bangladesh have been amply documented. There are also many studies of women's participation in ethnic secessionist and religious nationalist movements. There is a long standing charm between 
scholarship on movements and on parties. It has to do with the compartmentalization of knowledge that historically separated the study of conventional and unconventional politics. Charles Tilly et. al. argue in Dynamics of Contention that reification reached its peak in American social science during the 1950s and 1960s. In William Gamson's ironic phrase, to "the social psychologist whose intellectual tools prepare him to better understand the irrational". The discipline thus relegated to the sidelines of academic left those who questioned dominant arrangement of power.

It is not correct to draw hard and fast lines between social movements and political parties. Most of the works on political parties draws on the experiences of Western Europe and the United States, which have very well institutionalised party systems. By contrast, political parties in South Asia are less institutionalised, more loosely knit entities. Due to loyalties to particular leaders, kinship ties, societal group, formed around religious, caste or ethnic identities which often leads to factionalism and the formation of new parties.

Here it is proper to draw broad distinctions between political parties and social movements on the basis of the different realms in which they organise and different constituencies they attract. In certain cases, the unattainable goals are achieved by the alliances of parties and movements. Parties have often been averse to provide women institutional access, whereas social movements have organised women extensively out side the former range of power. Often they were reluctant to raise women's interest and confront gender inequality. Parties, often employ the tactics of social movements or make alliance with them to enlarge their electorates.

The intersection of party and movement based mobilisation of women has acquired unprecedented importance, with the growth of ethnic and religious political parties. Many of them have been extremely successful in organising women. Examples include the Jam'at-e-Islam in Pakistan and Bangladesh, the Janatha Vimukthi Peramuna (JVP) and Liberation Tigers of Tamil Eelam (LTTE) in Srilanka, and the Bharatiya Janata Party (BJP), Telegu Desam Party (TDP) and Dravida Munnettra Kazhagam (DMK) in India. These parties have not only mobilized women around elections as "vote banks", they have also made them figure heads and spokespersons for their parties, and often militant one too, which have inspired them to sacrifice themselves for nationalist causes. But they have not offered them lasting institutional power or rights that would increase their autonomy from their families.

Social movements and political parties are deeply intertwined through their genesis in nationalist movements in many parts of the post -colonial world. Though, the major political parties are the products of nationalist movements in the region. Through these national social movements that women were often active for the first time in politics. The first national political parties were formed out of these movements throughout South Asia, and women were often prominent in them.

However, the marked difference are even more worth-mentioning. First, while South Asian countries share a colonial past, their nationalist movements and women's relationship to nationalism differ significantly. None other than any countries, India stands out as having experienced the longest, largest and mass based nationalist movement, which involved extensive participation of women. The women who gained access to power in the aftermath of independence were active in the nationalism movement. Further, the Congress Party's recognition of their rights after independence was achieved with women, contribution to nationalism. Women's involvement in the Indian nationalist movement set an example that male and female nationalists in other parts of South Asia emulated.On the other hand, the partitions that brought about the creation of Pakistan and Bangladesh did not greatly mobilize women, and resulted in violence.

Second, the extent to which parties represent women and take up their interests is closely linked up to the health and vitality of democratic processes. However, the strength of civil society initiatives is not entirely dependent on the strength of political institutions, during a period of regression the women's movements in Pakistan was remarkable. Conversely, strong political institutions and parties do not guarantee the representation of women's interest. An important yardstick of the strength of both political parties and movements is the ability of women's movement to work with parties to increase women's representation and address gender inequality. In this respect, India is at the better position compared to other countries due to strong political parties and civil society organisations.

Democracy is considered to be a part of both the solution and problem. Civil society gives rise not only to feminist and human rights movements, but also to chauvinist ethnic and religious nationalist movements, which have strong ties with parties. Therefore, democratisation may paradoxically be linked with the growth of anti-democratic movements.

Regarding women, the ethnic and religious parties have some unique features. In general, women have given less access to institutional power within the party. They may involve in activities such as armed combat that break with their traditional gender roles. In nationalist terms, their goals often undermine women's rights. In India, the relationship between movements and parties is a lens on the complex character of Indian democracy. Here I will discuss three of the major political parties, who have approached women and women's issues in different manners- the Congress Party, the Bharatiya Janta Party (BJP) and the Communist Party of India (Marxist) (CPM). 
In an opportunistic manner, political parties have approached female vote banks. In their party manifesto they have made numerous promises that they have not fulfilled. The under- representation of women is visible in political office, in parliament and in higher level decision- making bodies of the government and political parties.

In political parties and elections, the real drama of Indian politics is prominent. The Congress led nationalist movement involved extensive women's participation, both at the levels of elite and rural poor. Through the nationalist movement, in the post-independence period, most prominent women leaders in India engaged in politics. The reason behind the Congress party decline was the widespread of women's disenchantment in the heightened form. During Nehruvian period, Congress has been committed to social democratic redistribution reform and poverty allevation. In late 1980 s and early 1990 s, the commitment waned because party moved to a centrist, right -wing position which resulted in lost of support among poor men and women.

From women's viewpoint, more significant was Congress's waning commitment to secularism. Congress tried to pass the Hindu code Bill providing equal right to men and women within the family in 1944, but due to opposition the bill could not pass until 1955, In late 80's in the Shah Bano issue, an elderly Muslim women sought maintains from her husband under the India Panel Code, and when verdict was in her favour, the orthodox Muslim community forcefully opposed his decision. In 1986, the then Prime Minister, Rajiv Gandhi appeased it by passing the misleadingly titled Muslim Women's Protection of Rights in Divorce Act, which denied Muslim women the right to demand maintenance from their husbands beyond a three month period. The women's rights were linked to the secular democratic framework, an increasing chasm developed between the Congress party and the women's movement.

After the spilt in 1964, the Communist Party of India (CPI) and the CPM were active in mobilizing women and all had strong women's organisation. But, these organisations were unequivocal in subordinating issues concerning gender to those of class inequality. In the early 1980 s due to the growth of the autonomous women's movement and the growth of the religious right, led some of the younger Communist activists to raise questions of gender inequality more vigorously. The National Federation of India women (NFIW), which was affiliated to the CPI, played an important role. In 1981, CPM formed the All India Democratic Women's Association (AIDWA), it joined actively with autonomous women's groups and look up issues of violence against women.

Women played an significant roles in Hindu nationalism. Vijayraje Scindia, Uma Bharati and Sadhvi Rithambara were most extraordinary orators in the movements, during late 1990s and early 1990s. They were in Ayodhya, in December 1992, inspired and ignite the mobs to destroy the mosque. Their voices were banned by the government because they were filled with anti -Muslim propaganda and injunctions to violence.

This association of women is not restrict to leadership level. Thousands of ordinary women were associated in violent Hindu campaigns. The Durga Vahini and the Rashtrasevika Samiti, the women organisations affiliated to the VHP and RSS, train women to use rifles and wield lathis (large stick) .Since early 1990s, they played an important role in many riots during that period, directing Hindu mobs towards Muslim localities, preventing the police from aiding Muslim families, and engaging in post riots looting of homes and shops. In 2002, Gujrat riot Hindu women's organisations either participated in the violence or at best failed to prevent it.

BJP has itself presented as an advocate of women's rights. It has taken a strong step in favour of the Uniform Civil Code (UCC) which would extend the same eight the same right to men and women regardless of their religious backgrounds. It has expressed a commitment for reservations of women in parliament. It has condemned sexual violence and supported the creation of more employment opportunities for women.

In 2004 elections, though there were differences between BJP and the Congress Party, but the similarities are more noticeable. The BJP look a lead in incorporating into the NDA manifesto promises to unveil a national policy on women's economic empowerment, which would ensure some means of livelihood for all women and would increase the incomes of all categories of working women. It commits itself to a national childcare plan, workplace flexibility, greater career opportunities, hostels for working women in every town and the removal of gender disparities in education, wages and property rights. It promises to promote female self-employment and entrepreneurship; to enforce laws against female foeticide, dowry, child marriage, trafficking, rape and family violence, and to introduce a bill reserving 33percent seats for women in parliament and state legislatives in the very first session of parliament.

The Congress Party manifesto covers much of the some ground as the BJP's. It also supports 33 Percent reservation for women in parliament, legislation curbing the dowry, raising the age of marriage and improving widows' conditions. It further pay more attention to decentralization through the panchayats and complete legal equality for women. This includes giving women and equal share in matrimonial property by protecting their rights to matrimonial homes by giving them equal rights of ownership of assets such as houses and land. 
When the BJP has taken up certain women's rights, such as the UCC, it has done so on grounds of political expediency. Its support for the UCC issue in the 1990s was in part a response to the Shah Bano issue. It was designed to signal that unlike the Congress Party, which was swayed by religious fundamentalist, the BJP was committed to secularism, and that unlike Muslims, who were committed to religions law, Hindus accepted the secular law. Expediency has also meant that the position the BJP women's organition assumes are often inconsistent. Although members of Mahila Morcha (women's organisation affiliated to the BJP) voice the party line on the Ram Janambhoomi movement, it is difficult to identify a single one of the vital issues before the women's movement dowry, sati, female foeticide-on which the BJP holds a unified position. Like other political parties, BJP also failed to keep all its promises like it does not implement reservations for women till the date.

The positions of BJP can be best explained by its combining party and movement identities. BJP as a political party, is guided by an electoral logic that has entailed extending its support base from upper caste, upper class men to a much broader constituency that includes women and lower caste groups. As it is linked up with the RSS and the VHP, the BJP also seeks legitimacy on the basis of military movement identity. The Mahila Morcha is responsible for electoral campaigns, where as Rashtra Sevika Sangh and the Durga Vahini, which are respectively affiliated with the RSS and the VHP; refrain from direct involvement in party politics. Their work includes educating girls and women in the principles of Hindu Nationalism, and trained them to fight for a Hindu State.The combination of party and movement based identities are the key to the success of Hindu nationalist. It provides a more effective means of influencing the state than to approach in isolation.

Election:- The number of women candidates that political parties have nominated to run for office is very numerous. During the 1980s and 1990s when the women's movement was in full swing but their number did not increase. The percentage of candidates from all parties who were women was 4.5 percent in 1984 and increased in the intervening election to $7.6 \%$ in 1999 . The proportion of female candidates who were elected in $1990,8.9 \%$ was hardly greater than in 1984 , at $8.2 \%$. This shows the party hypocricy and biases regarding the under representation of women's in party office. In 1999, women constituted $7.6 \%$ of all candidates and $23.3 \%$ of all candidates who were elected. So the small proportion of women stood for office had a relatively high likelihood of electoral success. Similarly, in the preceding elections in 1984, 1989, 1991, 1996, and 1999 a far greater proportion of women (two or three times more) were elected than were nominated to stand for office.Because the, parties put women only in constituencies they were confident that they would win. Like 61.8 percent of women candidates were elected in 1984 fits this explanation. In 2004 Lok Sabha elections, from national parties the number of seats women contested were 110 and they won 30 seats,that is., $27.27 \%$ and at state level out of 66 seats they won14 seats that means $21.21 \%$. In 2009, from national parties the number of seats women contested were 134 and they won 43 seats, that is., 20.37\%. In 2014 Lok Sabha elections, from national parties the number of seats women contested were 146 and they won 62 seats, that is $24.66 \%$ and at state level they won $3.09 \%$.This shows the down trend in women's election. This shown in the tables given below:-

\section{WOMEN'S MOVEMENTS AND POLITICAL PARTIES}

In post-independence period, followed by Indira Gandhi's declaration of state of national emergency (1975-77) was the major period social movement activism and fliration with authoritarism. Many movements emerged, opposing deforestation, the violation of tribal land rights, the mistreatment of slum dwellers and the oppression of lower castes. In these grass roots movements, women and question of gender inequality were at the forefront. During the same period, numerous urban feminist organisations were formed autonomously from political parties. They were the Samata Manch (Equality Forum) Stree Sangharsh Samiti (Women's Struggle Committee ) Stree Mukti Sangathan (Women's Power Organisation), the Feminist Network collective, Stree Shakti Sangathan (Women's Power Organisation), Purogami Sangathan (Forward Stepping Organisation), the Forum Against Oppression of Women, Saheli, the Progressive Organisation of Women, the Women's Center Kali for women and Manushi. There are range of issues addressed by them but the main concern was violence against women.

The most important gains women achieved were in the courts and bureaucracy, not in the electoral arena. The government appointed women to some key posts, and created bodies to investigate women's conditions and make recommendations. The National Commission on the Status of women was the most significant among them. Cases that were lodged in the court often remained there for a long time, legal battles diverted women's interest and identities. They could seek redress while placing pressure on the courts and segments of the bureaucracy to address the conditions of marginal groups.

Both grass roots movements and the feminist movement put less effort into electoral parties and has less impact on it. Unlike a range of other social movements, the women's movement played a relatively small role in two social elections that removed the Congress Party from power (in 1977 and 1986). For total democracy in 1977, the Gandhian Socialist leader Jayaprakash Narayan organised the movement for total democracy which brought the downfall of Congress and election of the Janata Party. V. P. Singh resigned from 
Congress a decade later and formed the Jan Morcha (Peoples" Front) a non-political movement that brought new groups into politics and helped bring the National Front to power in 1989. During this time women's movement began to interact more closely with political parties and the state.

During the past two-three decades we have witnessed a conjunction of two trends. One, an efforts by political parties to foster closer ties to social movements and non-governmental organisations, and the second, the attempts are made by some women's movement activists to work with parties and the state.

In an area where the women's movement has most closely interact with political parties is their demand to pass bill supporting reservations for women at the national level. There has been a great deal of debate within both the women's movement and political parties about the desirability of reservations for women in the legislative Assembly and Parliament. The urban feminist movement may be national in character but localised in practise, they largely reported reservations but political parties have not actively supported them.

Starting from 1996, the govt who have supported the $81^{\text {st }}$ Amendment Bill guaranteeing at least $33 \%$ of reserved seats for women in parliament and the legislative Assembly. They have also endorsed in their respective manifesto but they did not supported, its passage in parliament. In December 2000, it was defeated when a range of parties expressed their ambivalence or opposition to it. The then Home Minister, L. K. Advani supported the Chief election commissioner's proposal to require all political parties to reserve $33 \%$ of seats for women contestants. Parties records in nominating women candidate have been low. In 1996 parliamentary election, women comprised less than $15 \%$ of the total number of candidates put up by political parties. Women constitute only $10-12 \%$ of the membership of political parties .

Political Parties have been more resistant than the general public to state and national level reservation for women. A survey by India Today that indicates that $75 \%$ of women and $19 \%$ of men favour the active participation of women in politics, and $75 \%$ of men and women favour reservation in legislative bodies. But the left-leaning parties have often opposed the bill on ground that it does not take account of caste inequality. The Janata Dal, Rastriya Janata Dal,(Laloo Prashad Yadav) Samajvadi Janata Party and Bahujan Samajwadi Parties Background Class (OBCs)

The opposition to the $81^{\text {st }}$ Amendment from some segments of the women's movement partly reflect a distrust of political parties. The reasons are -

i)quotas could form a ceiling rather than a minimum to be improved upon,

ii)women candidates might be pliable because of their dependence on male party leader.

iii) more important is that reservations treat women as a homogeneous group, which increases the likelihood that the "biwi bridge' of educated, upper caste women will be elected, particularly because the bill does not provide for sub-quotas of OBCs.

Women's Leadership: - Some women have been elected to Parliament with solid support from a constituency committed to women's advancement, and women MPs have been relatively ineffective in challenging gender inequality. The representation of women in Parliament has not increased much from $4.7 \%$ (or 22 women) in the first Parliament (1952-57). The largest property ever was $8.1 \%$ (44 women) in Parliament elected in 1984. Between 1991 and 96, 49 women were elected to Parliament (5.2 Percent). Women occupied 4.1 Percent of 22 percent of Parliamentary seats that were reserved for scheduled castes. Most of them were upper caste, and two were from scheduled Tribes. Most women MPs are middle class professionals.

Generally, the power of women MPs is very limited. Because they are respected to support the party line rather then to formulate their own agendas, they have accorded low priority to issues concerning women. The exception here is that women's wings to political parties liaise with women MPs, who can thus become conducts between the party leadership and its women members. They are also consulted from time to time by the party leadership on issues regarding the family and women's rights. But non-party women's group do not seem to approach women MPs.

The women's movement is at even greater remove from the smaller and more exceptional group of female party leaders. Considering, the roles of women who have emerged as powerbrokers within Indian politics. They include the Italian born Sonia Gandhi, who was positioned to become Prime Minister in 2004, Jayalalitha Jayaram, who heads the regionally based All India Anna Dravida Munnetra Kizagam (AIADMK) from the southern state of Tamil Nadu, Mamata Banerjee; the head and of the Trinamul Congress Party and the Chief Minister West Bengal; Mayawati, and Rabri Devi previously the Chief Minister of Uttarpradesh, and Bihar. Among them, Gandhi, Jayalalitha and Mayavati, were directly responsible for the downfall of Bharatiya Janata Party government. At Sonia Gandhi's prompting, Jayalalitha withdraw her party's support from the central government. Mayavati hammered the last mail by voting against the government in a critical parliamentary vote, there by causing in a new election.

All these women, with possible exception of Mayavati, rose to power as subordinate or dependent to men rather than through movements or institutional channels. Rabri Devi only emerged from her role as housewife and mother of nine children where her husband was imprisoned and she replaced him as chief minister of Bihar. Jayalalitha was the mistress of actor turned politician. 
M.G. Ramachandran, whom she succeeded as chief ministers of Tamil Nadu. Sonia Gandhi is the widow of the former Prime Minister Rajiv Gandhi and daughter-in-law of Indira Gandhi . Sonia Gandhi's popularity precipitated a backlash against her. The BJP engaged in a vicious summer campaign that directed attention to her foreign origins, leading her withdraw her candidacy for primeministership.Indian's women leadership may be important symbols of the nation and its parts, but due to lack of the support of movements, they became less powerful in their own right. In the absence of such support, their connections with male family members assume paramount importance. Nor do these women share common values, ideas or agendas. Their role in bringing down the BJP govt. may be as close as they will ever come to collaborating. Their deepest commitments are to their parties and to themselves, not to collective interests of women.However, there is enormous scope for alliance between the women's movement, as it seeks out a national presence and a role in the state, and the small number of party women who are staking out independent position. It is exactly such an alliance that is needed to address that Gail Omvedt identifies when she describes the women's movement as anti-political. There is no question that the farmers movement and the caste-based, ethnic and religious nationalist movements have all had a much bigger impact that the women's movement on electoral politics. The question of how to engage in election selectively and electively poses an important challenge for women's movement.

\section{CONCLUSION}

This paper is about the relationship between women and parties and between parties and movements. What is worth-mentioning here is the dearth of scholarship on these relationships and their political significance. Though parties have neglected women's interests, they have profited from employing gendered imagery, drawing on women's votes and using women in electioneering. Keeping this in view, there are some important differences among political parties. The first is ideological. Left-of-centre parties are more likely to address questions of gender inequality, but not necessarily to have better representation of women in leadership positions. Leftist parties are most apt to commit themselves in principle to the eradication of gender inequality, which provides a normative standard to which their party leaders can appeal. Women's movements are also most likely to seek out alliances with leftist parties and then pressuring them to hold to their stated commitments.

The second is it concerns of nationalism which differentiating among parties with respect to their stance on women cuts across ideology;. Nationalist parties, most of which are ethnically and religiously based, have been especially effective in mobilizing support through gendered appeals. In leadership positions, the actual number of women involved in these movements is relatively small, but their symbolic presence is utmost important.The biggest obstacle that confronts any serious attempt to challenge gender inequality through the party system is that parties draw on women's participation as individuals, not as members of a group that has suffered discrimination. Women's sense of collective identity further undermines their participation in party politics. Not surprisingly, those women who have achieved positions of political power in South Asia do not owe these positions to political parties. Neither the parties lived up to their expectation for addressing gender inequality.

Different women's and social movements have played a critical role in placing women at the forefront of the political agenda. However, they have given little attention to working with parties through the electoral system than to other areas. Many women's struggles have been waged in the courts and in bureaucracies. Women's movements have generally not developed alliances with political parties or with women MPs. There are exceptions to this rule, however. In India, leftist political parties and their women's organizations have had closer relationships than centrist and rightist parties with autonomous women's movements.

However, women's movements have become more receptive to alliances with political parties and more interested in influencing political processes than they were in the past. This is due to the growth of ethnic and religious nationalism, which has posed a direct challenge to women's movements and led them to seek alliances with secular, democratic parties. International influences may also play an important role. Many Western funding agencies have sought to strengthen civil society organizations in response to neoliberal policies that have weakened states. One issue that women's movements have taken up is the demand for the reservation of parliamentary seats for women at the national level. This demand has encountered different challenges in each country.

In India, the women's movement has confront the challenge of accommodating caste inequality within reserved seats for women. Inspite of complexities revolves round the question of how reservations should be implemented, women's movements concur overall in their support. There is potential for South Asian women's movements to jointly formulate certain demands, such as making it legally mandatory for political parties to allot 33 per cent of tickets to women members. The major differences among South Asian countries regarding the characteristics of their political systems, which offer very different opportunities for women's political engagement. The stronger democratic institutions and practices are, the greater the opportunities this affords women to achieve representation through the party system. In India, has a long history of democracy, numerous 
and varied political parties, , open and regular elections have ensured that political parties have sought the support of the female electorate. This has often resulted in expedient appeals to women's interests, and also increased women's awareness of their powers. Women's movements are coming to form alliances with political parties encircling round a varieties of issues. But democracy presents its own challenges. The very alliance between certain civil society groups and political parties that is a product of democracy has also led parties to co-opt the demands of autonomous women's groups. The success of the movement and the party were thus inversely correlated. In India the very willingness of the right-wing BJP to take up the Uniform Civil Code has led the women's movement to shelve the demand temporarily in order to avoid being too closely associated with the party. A related problem is that the very growth of civil society associated with the spread of democracy is also responsible for the growth of conservative parties and movements.Indeed in all South Asian countries, right-wing groups, which are often ethnic and religious in character, have a big capacity to mobilize women's movements while undermining women's advancement. Thus amongst the major challenges that women's movements working in agreement with leftist and secular parties must be encountered. This could be solved, if every political parties have reservation for women folk in their respective organisations and also office-bearers of state and national political parties have $33 \%$ of reservation for women.

\section{REFERENCES}

[1] Brass, Paul. 1991. Ethnicity and Nationalism: Theory and Comparison.Sage, New Delhi.

[2] Brass, Paul. 2000. "The strong state and the fear of disorder." In Francine R. Frankel, Zoya Hasan, Rajeev

[3] Bhargava and Balveer Aurora (eds.), Transforming India: Social and Political Dynamics of Democracy. Oxford University Press, New Delhi.

[4] Chowdhury, Najma. 1994. "Gender issues and politics in a patriarchy." In Barbara J. Nelson and Najma Chowdhury (eds.), Women and Politics Worldwide. Yale University Press, New Haven.

[5] De Mel, Neloufer. 2001. Women and The Nation's Narrative: Gender and Nationalism in Twentieth Century.Rowman Littlefield, Lanham, Md.

[6] Eschle, Catherine. 2001. Global Democracy, Social Movements and Feminism.

[7] Westview, Boulder, Colo.

[8] Gamson, William. 1990. The Strategy of Social Protest.Wadsworth, Belmont, Calif.The Hindu."How Enabled?" 10 March 2002.

[9] www.hindu.com/thehindu/mag/2002/03/10/stories/2002031000010100.htm accessed on 10 March 2004.

[10] Jahan, Rounaq. 1995.

[11] The Elusive Agenda: Mainstreaming Women in Development.Zed, London.

[12] Kannabiran, Vasanth and Kalpana Kannabiran. 1997. "From social action to political action: Women and the 81st Amendment." Economic and Political Weekly,1 February, pp. 196-197.

[13] Kishwar, Madhu. 1996. "Women and politics: Beyond quotas." Economic and Political Weekly,Vol. 31, No. 43,26 October, pp. 2867-2874.

[14] Kohli, Atul. 2001. Democracy and Discontent: India's Crisis of Governability.

[15] Cambridge University Press, Cambridge

[16] Kumari, Abhilasha and Sabina Kidwai. 1998. Crossing the Sacred Line: Women's Search for Political Power. Orient Longman, New Delhi.

[17] Omvedt, Gail. 1993. Reinventing Revolution: New Social Movements and The Socialist Tradition in India.ME Sharpe, New York.

[18] Rai, Shirin M. 1997. "Gender and representation: Women MPs in the Indian Parliament." In Anne Marie Goetz(ed.), Getting Institutions Right for Women in Development.Zed, London.

[19] Rai, Shirin M. 2002. Gender and the Political Economy of Development: From Nationalism to Globalization. Polity,Cambridge.

[20] Rai, Shirin M. and Kumud Sharma. 2000. "Democratizing the Indian Parliament: The reservations for women debate." In Shirin Rai (ed.), International Perspectives on Gender and Democratisation.MacMillan, Basingstoke. 